\title{
RNA-Seq analysis and transcriptome assembly of Salicornia neei reveals a powerful system for ammonium detoxification
}

\author{
Mónica Díaz-Silva ${ }^{1}$, Jonathan Maldonado ${ }^{2}, N$ icol Delgado ${ }^{1}$, Pamela Veloso $^{1}$, Herman Silva ${ }^{2}$, \\ José A. Gallardo ${ }^{1}$ \\ ${ }^{1}$ Laboratorio de Genética y Genómica Aplicada, Escuela de Ciencias del Mar, Pontificia Universidad \\ Católica de Valparaíso, Valparaíso, Chile \\ ${ }^{2}$ Laboratorio de Genómica Funcional \& Bioinformática, Facultad de Ciencias Agronómicas, \\ Universidad de Chile, Av. Santa Rosa 11315, 8820808 La Pintana, Santiago, Chile.
}

\section{ABSTRACT}

Background: Salicornia neei is a halophyte plant that has been proposed for phytoremediation of saline wastewater generated by land-based aquaculture, which usually contains elevated concentrations of ammonium resulting from protein metabolism. To identify the molecular mechanisms related to ammonium response through of analysis results in silico and the MichaelisMenten ammonium removal biokinetics and the transcriptome of $S$. neei in response to growth in saline water containing $3 \mathrm{mM}$ ammonium.

Results: The parameters for ammonium uptake by $S$. neei root cuttings were estimated: 1) maximum uptake rate $\operatorname{Imax}=7.07 \pm 0.27 \mathrm{mM} \mathrm{N} \mathrm{g}^{-1}$ fresh weight $\mathrm{h}^{-1}$; and 2) half-saturation constant $\mathrm{Km}=0.85 \pm 0.12 \mathrm{mM} \mathrm{N} \mathrm{L}^{-1}$. Further, a total of 45,327 genes were annotated, which represents $51.2 \%$ of the contig predicted from de novo assembly. A total of 9,140 genes were differentially expressed in response to ammonium in saline water, but only 7,396 could be annotated against functional databases. According to the GO enrichment and as well as KEGG pathway analyses showed these upregulated genes were involved in pr cellular anatomical entity, cellular process, and metabolic process, including biological KEGG pathways linked to biosynthesis amino acid biosynthesis, nitrogen metabolism and autophagy and other. In addiction, a set of 72 genes were directly involved in ammonium metabolism, including glutamine synthetase 1 (GLN1), glutamate synthase 1 (GLT1), and ferredoxin-dependent glutamate synthase chloroplastic (FdGOGAT).

Conclusion: Our results support the hypothesis that an ammonium detoxification system mediated by glutamine and glutamate synthase was activated in S. neei when exposed to ammonium and 
saline water. These results provide novel insight into understanding the molecular mechanisms of ammonium nutrition and aid for investigating the response of halophyte plants to saline wastewater from land-based aquaculture

Keywords: saline wastewater; ammonium response; Salicornia neei; de novo assembly; RNA-seq; succulent hydrohalophyte; aquaculture; nitrogen metabolism; leafy green food

\section{Introduction}

Salicornia neei has been proposed for the treatment of saline wastewater from land-based aquaculture effluents in South America [1]. S. neei is a succulent hydrohalophyte of herbaceous habit that is abundantly distributed throughout much of the western coastline of the South Pacific [2]. Similar to other related species from Europe and North America, S. neei has attracted great interest due to its potential as a leafy green food because it contains significant amounts of nutrients and functional metabolites $[3,4]$. Its potential to germinate and be cultivated in different salinity gradients and nitrogen concentrations has recently been evaluated in landbased white shrimp (Litopenaeus vannamei) farming systems $[5,6]$ and constructed wetlands (CWs) [1].

Land-based monoculture production systems use a large amount of artificial food that is rich in nitrogenous compounds which are not fully utilized and may contaminate the culture water [7] or the environment if they are discarded without treatment. Although the accumulation of these compounds is variable and depends on both the species and water treatment system involved [8], studies have shown that $133 \mathrm{~kg}$ of nitrogen $(\mathrm{N})$ is released into the environment for each ton of harvested production [9]. The main nitrogenated compounds that are generated as waste are ammonia $\left(\mathrm{NH}_{3}{ }^{+}\right)$and ammonium $\left(\mathrm{NH}_{4}{ }^{+}\right)$, which are generally the final products of protein metabolism [10]. These compounds are found in equilibrium depending on the $\mathrm{pH}$, temperature [11], and salinity [12]. The accumulation of ammonia and ammonium and other derived products, namely, nitrate $\left(\mathrm{NO}_{3}^{-}\right)$and nitrite $\left(\mathrm{NO}_{2}^{-}\right)$, deteriorate water quality [13-15] and can generate eutrophication processes [16-20] and even encourage the development of diseases in cultivated organisms [21]. Therefore, taking advantage of nitrogenated compounds through the implementation of integrated marine aquaculture systems with halophyte plants has been proposed as a more sustainable alternative for the future development of land-based marine aquaculture $[8,22]$. 
Nitrate and ammonium, which are the main forms of inorganic $\mathrm{N}$ that plants absorb, act as nutrients and signals, affecting the growth and metabolism of the plant [23]. In general, the preference of plants towards nitrate or ammonium depends both on the genotype and on environmental variables such as soil pH and the availability of other nutrients [24].

Ammonium is a nutrient with rapid absorption but excessive accumulation in tissues; in plants, high concentrations can lead to symptoms of toxicity if it is the only source of $N$ [25]. However, the addition of ammonium and nitrate together can be favorable for the plant, showing a synergistic response [26]. In ammonium-tolerant plants, such as of the Salicornia genus, $\mathrm{NH}_{4}{ }^{+}$assimilation activity is higher compared to glycophytes. Ammonium stimulates its assimilation by the upregulation of several key enzymes involved in ammonium metabolism [27, 28]. After direct uptake or conversion from $\mathrm{NH}_{3}{ }^{+}, \mathrm{NH}_{4}{ }^{+}$is assimilated to glutamine and glutamate via the activity of glutamine synthetase (GS), glutamate synthase (GOGAT), and glutamate dehydrogenase (GDH). The products of these pathways are required for the biosynthesis of other nitrogenous compounds [29]. These enzymes are part of two distinct pathways, the GS/GOGAT and GDH pathways. GS assimilates ammonium by catalyzing the amination of glutamate to form glutamine, while GOGAT catalyzes the reductive transfer of an amide-amino group from glutamine to 2-oxoglutarate with the production of glutamate. GDH catalyzes the reversible amination of 2-oxoglutarate and ammonium to form glutamate [30].

In most glycophyte plants, highly saline soil disrupts metabolism, mainly due to decreased $\mathrm{N}$ uptake, altered activities of nitrate $\left(\mathrm{NO}_{3}\right)$, and ammonium $\left(\mathrm{NH}_{4}{ }^{+}\right)$-assimilating enzymes, inducing changes in amino acid synthesis and increasing the activity of hydrolyzing enzymes such as RNase, DNase, and protease that lead to macromolecule degradation [31]. However, halophytic plants have the enzymatic potential to synthesize GS, GOGAT, and GDH to assimilate ammonium under saline conditions [32]. These enzymes have been demonstrated to be powerful regulators of gene expression and may be involved in diverse stress responsiveness [33]. For example, many halophytic plants accumulate large amounts of soluble nitrogenous compounds that are involved in salt tolerance, such as proline and the proline analog 4-hydroxy-N-methyl proline, glycine betaine, pinitol, myoinositol, mannitol, sorbitol, 0-methylmucoinositol, and polyamines (PAs) [32, $34,35]$.

To identify the molecular mechanisms related to ammonium response, we conducted transcriptomic analysis of $S$. neei in response to ammonium in saline water. It was expected that $S$. 
neei would have a gene response profile typical of halophyte plants when exposed to abiotic stressors of both ammonium and salinity.

\section{Materials and methods}

\subsection{Plant material collection}

S. neei wild plants were collected from "Pullally" salt marsh (Papudo, Chile; latitude, $32^{\circ} 24^{\prime} 50^{\prime \prime}$; longitude, $71^{\circ} 23^{\prime} 35.01^{\prime \prime} \mathrm{W}$ ) (Fig. 1) and transported to the facilities of Marine Farms Inc. (Laguna Verde, Chile, latitude $33^{\circ} 6^{\prime} 36^{\prime \prime} \mathrm{S}$; longitude $71^{\circ} 40^{\prime} 48^{\prime \prime}$ ) ) to propagate the plants using cuttings. Stem cuttings were placed in an aquaponic cultivation system until they developed roots. Then, 180 rooted cuttings of $S$. neei were obtained from Marine Farms Inc. and transported to controlled growth chambers at the Pontificia Universidad Católica de Valparaíso (Valparaíso, Chile, latitude $33^{\circ} 1^{\prime} 21^{\prime \prime} \mathrm{S}$, longitude $\left.71^{\circ} 37^{\prime} 57^{\prime \prime} \mathrm{W}\right)$. The cuttings were acclimated for 7 days in hydroponic culture pots using UV-filtered seawater $(600 \mathrm{mM} \mathrm{NaCl})$ to remove suspended particles and microorganisms. The cuttings were reared in a $12 \mathrm{~h} / 12 \mathrm{~h}$ (day/night) photoperiod cycle at a temperature of $20{ }^{\circ} \mathrm{C}$ and constant oxygenation until being used in the ammonium removal biokinetics or RNA-seq experiments. No extra nitrogen source was added to the filtered seawater during the acclimatization period, which had a basal concentration of $28 \pm 6.5 \mu \mathrm{M} \mathrm{L}^{-1}$ of ammonium.

\subsection{Michaelis-Menten ammonium removal biokinetics}

A total of sixty cuttings were used to characterize the Michaelis-Menten ammonium removal biokinetics. They were randomly distributed in five treatments that consisted of filtered seawater solutions with the addition of ammonium chloride $\left(\mathrm{NH}_{4} \mathrm{Cl}\right)$ at the following concentrations: $0,1,2$, 3 , and $4 \mathrm{mM}$. Each treatment was set up in $500 \mathrm{~mL}$ flasks in which 4 cuttings with an average weight of $21.8 \pm 9.9 \mathrm{~g}$ were placed (Supplementary Fig. S1). For each treatment, a flask without plants was also used as a control or blank. Ammonium removal was evaluated every 60 min for a period of $5 \mathrm{~h}$. At each time point, two $1.5 \mathrm{~mL}$ samples were taken from the treatments and control and stored in Eppendorf tubes for subsequent analysis. The Nessler method [36] was used for the determination of ammonium, using a HACH DR2800 spectrophotometer at $425 \mathrm{~nm}$. The ammonium uptake rate was expressed in $\mu \mathrm{M} \mathrm{NH}_{4} \mathrm{Cl} \mathrm{g}^{-1} \mathrm{DW} \mathrm{h} \mathrm{h}^{-1}$. After uptake, the root fresh 
weights were also recorded. The regressive relationship between uptake rate and ammonium concentration in the external solution was illustrated with the Michaelis-Menten [37] equation as follows:

$$
\mathrm{I}=\frac{\operatorname{Imax}[\mathrm{C}]}{\mathrm{Km}+[\mathrm{C}]}
$$

where $\mathrm{I}$ is uptake rate, Imax is the maximum uptake rate, $\mathrm{Km}$ is the half-saturation constant (Michaelis-Menten constant), and $\mathrm{C}$ is the ion concentration in solution. Michaelis-Menten curves were fitted using RStudio 7.0.

\subsection{RNA-seq experiment and RNA extraction}

A total of 24 cuttings were transferred to six plastic culture pots (four cuttings per pot and three biological replicates) containing $500 \mathrm{~mL}$ of filtered seawater with 0 or $3 \mathrm{mM} \mathrm{NH}_{4} \mathrm{Cl}$. After $2.5 \mathrm{~h}$, the cuttings were harvested for analysis. Approximately $1 \mathrm{~g}$ of collected stem tissue was extracted from each cutting, immediately frozen in liquid nitrogen, and stored at $-80^{\circ} \mathrm{C}$ until RNA extraction (Supplementary Fig. S2). Total RNA extraction was performed on three biological samples at 0 and $3 \mathrm{mM}$ ammonium. RNA extractions were performed following the previously described pine tree extraction method [38] used in combination with $\beta$-mercaptoethanol [39] and TRIzol (Life Technologies, Corp., Carlsbad, USA) according to the manufacturer's protocol. To homogenize the sample, it was ground in a mortar and pestle in the presence of liquid nitrogen and subsequently heated at $65{ }^{\circ} \mathrm{C}$ for $5 \mathrm{~min}$ in the presence of $1 \mathrm{~mL}$ pine tree buffer (PTB). Then, $20 \mu \mathrm{L} \beta$ mercaptoethanol was added to achieve greater sample purification, and the TRIzol steps were carried out according to the manufacturer's protocol. Each sample was eluted in $60 \mu \mathrm{L}$ of DEPC water and subjected to quantification by fluorometry using a Nanodrop (Biotek). Then, $5 \mu \mathrm{g}$ of each sample was treated with RNase-free DNase I (Thermo Fischer Science) to remove residual genomic DNA and precipitated with $3 \mathrm{M} \mathrm{NaAc}$ pH 5.2 and $100 \% \mathrm{EtOH}$. Finally integrity was evaluated by electrophoresis in a $1 \%$ agarose gel as described in [40].

\subsection{Library construction, deep sequencing, and de novo transcriptome assembly}


Library construction and deep sequencing of $S$. neei following treatment with 0 or $3 \mathrm{mM} \mathrm{NH}_{4} \mathrm{Cl}$ were performed at Macrogen (Inc. Seoul, South Korea) using the Solexa HiSeq2000 platform with the Truseq mRNA library previously constructed for paired-end application, according to Macrogen's protocol. For de novo transcriptome assembly, the raw data was cleaned of adaptor sequences, low-quality reads ( $Q$-value $\geq 20$ ), reads with poly- $N$ segments (reads containing more than $50 \%$ unknown bases), and short reads (less than 50 base pairs (bp)). The sequence quality algorithm contained in the CLC Genomics Workbench version 8.0 (http://www.clcbio.com) was used for this purpose. These results were processed using the scaffolding contig algorithm in the de novo assembly function of CLC Genomics Workbench with default parameters. Each sample (0 and $3 \mathrm{mM} \mathrm{NH}_{4} \mathrm{Cl}$ ) was mapped separately against the assembled set of contigs using the RNA-seq tool of CLC Genomics Workbench with the following parameters: similarity $=0.9$; length fraction $=$ 0.6; maximum mismatches $=2$; and unspecific match limit $=10$. Paired reads were counted as 2 , and paired-end distances were set as $101 \mathrm{bp}$.

\subsection{Functional annotation and KEGG pathway assignment}

To identify the putative biological function, all assembled contigs were searched against public protein databases using the BLASTx algorithm of BLAST version 2.6.0+ [41]; the searched databases included the NCBI non-redundant (NR) protein database with an E-value cut-off of $10^{-5}$, the Kyoto Encyclopedia of Genes and Genomes (KEGG) pathway database with an E-value of $10^{-5}$, and the Clusters of Orthologous Groups (COG) with an E-value of $10^{-10}$. Furthermore, to consolidate the information, all contigs were assigned to Gene Ontology (GO) categories using the Blast2Go version 5.2 [42] software package and an E-value cut-off of $10^{-5}$. Finally, because the genus Salicornia is poorly represented in the protein databases, contigs were also aligned against the nucleotide sequences of Salicornia available from the NCBI database using BLASTn with an $\mathrm{E}$ value of $10^{-5}$.

\subsection{Differentially expressed genes (DEGs)}

To determine the differentially expressed genes in S. neei under the two nutritional conditions, RNA-seq analysis was performed using CLC Genomics Workbench program version 8.0 (http://www.clcbio.com). The relative transcript levels were defined as the number of reads 
that uniquely mapped to a gene. The expression levels were compared using a Z-Test [43, 44] with the $0 \mathrm{mM} \mathrm{NH}_{4} \mathrm{Cl}$ sample as the reference. This test compares counts by considering the proportions that make up the total sum of counts in each sample, correcting the data for sample size. For visual inspection, the original expression values were log10 transformed and then normalized using the quantile method that best fits the results [44]. As a significant threshold for the selection of genes with differential expression, a false discovery rate (FDR) $p$ value $<0.001$ and an absolute fold change (FC) of 2.0 were adopted. Finally, GO enrichment analyses were performed separately on genes upregulated in the 0 and $3 \mathrm{mM} \mathrm{NH}_{4} \mathrm{Cl}$ treatments to investigate the differences in the ammonium response mechanism.

\section{Results}

\subsection{Kinetics of ammonium removal}

The parameters of $\mathrm{NH}_{4}-\mathrm{N}$ uptake kinetics have not been previously determined for $\mathrm{S}$. neei. The ammonium uptake rate increased with increasing ammonium concentration in the external solution and tended toward saturation mainly in the range of 3 to $4 \mathrm{mM}$ (Fig. 2). Using regression analysis, it was found that the kinetic characteristics of ammonium uptake by the test plant could be illustrated using the Michaelis-Menten equation at a significance level of $p<0.001$. The kinetic parameters for ammonium uptake were estimated as the maximum rate ( $\operatorname{Imax}$ ) $=7.07 \pm 0.27$ and the half-saturation constant $(\mathrm{Km})=0.85 \pm 0.12$. Ammonium removal was significantly different from zero in all treatments (Supplementary Table S1).

\subsection{Transcriptomic sequencing, de novo assembly, and data availability}

The transcriptomic analysis of pooled samples resulted in a total of $146,780,108$ clean reads and 7.86 billion clean base pairs. The comprehensive reads were assembled into contigs using pairedend reads, resulting in 86,020 contigs with an average length of $586 \mathrm{bp}$ (Table 1 and Table S2). The raw sequencing data were deposited in the NCBI Short Read Archive (SRA) database under accession code SRR9694999 and have been assigned to the BioProject accession PRJNA554118.

\subsection{Overview of sequences annotation and differentially expressed genes (DEGs)}

The functional annotation process of contigs using the NR database determined the presence of 86,020 contigs, most of which were assigned to Spinacia oleracea and Chenopodium quinoa. Most 
sequence homologies were found from comparisons against the NCBI-NR database $(45,327$ contigs), followed by GO (37,784 contigs), and COG (20,047 contigs). Furthermore, 32,609 contigs were compared locally against the nucleotide sequences of Salicornia sp. Thus, a total of 13,906 new sequences from S. neei were found that did not match with those of other databases (Fig. 3). Based on the $S$. neei global transcriptome (86,020 contigs), 9,140 contigs were differentially expressed in the response to ammonium in saline water (7,040 upregulated and 2,100 downregulated), but only 7,396 could be annotated against the NR, GO, COG, KEGG databases. Moreover, 588 DEGs were unique to the ammonium treatment.

\subsection{Function annotation and classification}

A total of $150,944 \mathrm{GO}$ terms were assigned to 37,784 (43.9\%) of the analyzed sequences; in multiple cases, several terms were assigned to the same sequence (mean $=4$ ). Of the GO functional groups, 11 were assigned to biological processes, 10 to molecular functions, and 7 to cellular components. The top five functional groups were organic substance metabolic process $(18,160)$, intracellular anatomical structure $(18,042)$, cellular metabolic process $(17,526)$, primary metabolic process $(17,076)$, and orgnelle $(15,242)$ (Fig. 4). The GO terminology retrieved for the 4,850 DEGs of $S$. neei is summarized in Fig. 5. These pathways were divided into 67 terms with three categories, and the top five clades were "cellular anatomical entity" (2,579;53\%), "cellular process" (2,335; 48.1\%), “metabolic process" (2,010; 41.4\%), "catalytic activity" (1,852; 38.2\%), and "organic substance metabolic process" (1,748; 36\%) (Fig. 5). Moreover, the clades that were uniquely expressed under ammonium nutrition $\left(3 \mathrm{mM} \mathrm{NH}_{4} \mathrm{Cl}\right.$ in comparison with the control $(0$ $\mathrm{mM} \mathrm{NH}_{4} \mathrm{Cl}$ ) were "oxidoreductase activity" (328; 6.7\%), "transporter activity" (321; 6.2\%), and "transmembrane transport" (313; 6.4\%) (see Fig. 5). The top five GO enrichment analyses were associated with "cell wall biogenesis" (FDR $=3.24 \mathrm{E}^{-7}$ ), "xyloglucan metabolic process" (FDR = $\left.7.20 \mathrm{E}^{-6}\right)$, “heme binding" $\left(6.03 \mathrm{E}^{-7}\right)$, “UDP-glucosyltransferase activity" (FDR $\left.=8.03 \mathrm{E}^{-6}\right)$, and "plasma membrane" (FDR $=2.43 \mathrm{E}^{-9}$ ) (see Figure S3 and S4).

In the present transcriptome, several DEGs were identified related to $\mathrm{NH}_{4}{ }^{+}$response treatment this was reflected by transcripts for the majority of genes related to maintenance of homeostasis and stress response. For instance, nitrogen metabolism 91 DEGs whose 72 were up-regulated, glutamine synthetase (GS) (100-fold), oxoglutarate dehydrogenase (2-OGD) (2.34-fold), ferredoxin-dependent glutamate synthase chloroplastic (Fd-GOGAT) (4.29-fold), and glutamate synthase 1 [NADH] chloroplastic isoform X1 (GLT1) (6.74-fold) and ammonium transporter 
(AMT1) (2.39-fold) (Supplementary Tabla X). Phytohormone biosynthesis was also up regulated, we found DEGs related to ethylene biosynthesis like S-adenosylmethionine synthetase (SAdoMet) (20.82-fold), S-adenosyl-L-methionine (SAM) (4.8-fold), 1-aminocyclopropane-1carboxylate synthase (ACC) (13.96-fold) and abscisic acid biosynthesis like zeaxanthin epoxidase (ZEP) (2-fold), violaxanthin de-epoxidase, chloroplastic (VDE1) (2.56-fold), xanthoxin dehydrogenase (ABA2) (2-fold). The metabolism of polyamines (PAs) in plants is closely connected to ethylene biosynthesis, we found arginine decarboxylase-1 (ADC1) (2.36-fold), sadenosylmethionine decarboxylase proenzyme (SAMDC1) (2.25-fold), and polyamine oxidase-1 (PAO-1) (17.56-fold). Other candidate DEGs related to ammonium stress response were genes linked to autophagosome induction autophagy-related protein 1 (ATG1) (100-fold), autophagyrelated protein 13 (ATG13) (2.11-fold). Genes responsible for the progression like autophagyrelated protein 9 (ATG9) (5.89-fold), autophagy-related protein 2 (ATG2) (3.91-fold) and autophagy-related protein 18 (2.57-fold). Genes responsible for the vesicle nucleation like vacuolar protein sorting 34 (VPS34) (3.26-fold) and vacuolar protein sorting 15 (VPS15) (2.0-fold). Finally, genes responsible for the elongation and closure vacuolar protein sorting 8 (ATG8) (2.0fold) and phosphatidylenthanolamine (PE) (2.0-fold).

DEGs were almost mapped to metabolic pathway in KEGG, a total of 1,409 DEGs with pathway annotation and the results of main pathway are shown in table 3. Totally, 1,409 DEGs were mapped to 326 KEGG pathways and the global pathways with the highest number of overexpressed genes were secondary metabolite biosynthesis (297 DEGs), biosynthesis of antibiotics (95 DEGs), amino acid biosynthesis (71 DEGs). Several overexpressed genes were associated carbon metabolism (61 DEGs), starch and sucrose metabolism (55 DEGs), plant hormone signal transduction (53 DEGs). Finally, the function of the assembled contigs was further evaluated using Clusters of Orthologous Groups (COG) analysis. A total of 20,047 (23.3\%) sequences were assigned to 25 COG categories and specific functional groups were identified (see Fig. 6). In the 25 COG categories, the cluster for "function unknown" (9012, 44.9\%) represented the largest group, followed by "O: posttranslational modification, protein turnover, chaperones" (2,948; 14.7\%), and "T: signal transduction mechanisms" (3,031; 15.11\%). In addition, other important groups closely related to ammonium nutrition response and stress response were "E: amino acid transport and metabolism" (1,391; 6.9\%), "Q: Secondary metabolites biosynthesis, transport, and catabolism" (883; 4.4\%), "M: cell 
wall/membrane/envelope biogenesis" (486; 2.42), and "V: defense mechanisms" (259; 1.2\%). Only a small number of contigs were assigned to "W: extracellular structures" $(6 ; 0.02 \%)$ or "Y: nuclear structure" $(14 ; 0.006 \%)$.

\section{Discussion}

The use of halophyte plants to treat wastewater highly loaded with nitrogen compounds derived from the metabolism of aquatic organisms has been proposed to increase the sustainability of land-based aquaculture. However, the molecular mechanisms by which these plants can absorb and use these compounds in highly saline environments are poorly understood [20,45]. This work used transcriptome analysis of the halophyte plant $S$. neei to investigate possible pathways that are implicated in their response to ammonium nutrition. We considered possible ammonium homeostasis through ammonium metabolism and the encapsulation of ammonium in vacuoles to avoid increasing acidity in the apoplast. We studied the kinetics of ammonium absorption in concentration gradients to demonstrate the activity of HATS (high-affinity transport systems) (AMT1), which are mainly related to the entry of ammonium into the cell and, therefore, the disappearance of ammonium in the substrate.

The $\mathrm{NH}_{4}$ uptake kinetics of $S$. neei plants incubated at different concentrations fitted the Michaelis-Menten model well up to $4 \mathrm{mmol} \mathrm{L}^{-1} \mathrm{NH}_{4}$ (Fig. 1) advising plant HATS activity at the tested concentrations. Quinta et al. [7] found a good fit for the Michaelis-Menten model up to 2 mmol $\mathrm{NH}_{4} \mathrm{~L}^{-1}$ in S. europeae, and advice that HATS (high-affinity transport systems) are responsible for $\mathrm{N}$ uptake in that plant. In this study, S. neei had a higher ammonium absorption compared to S. europeae [7], demonstrating a better performance for use in aquaculture wastewater.

The Michaelis-Menten equations obtained with the tested ammonium concentrations (1 to $4 \mathrm{mM}$ $\mathrm{NH}_{4} \mathrm{Cl}$ ) describe changes in ammonium absorption according to the amount of ammonia supplied. It was found that $S$. neei had a high affinity for the substrate $\left(\mathrm{Km}=0.85 \pm 0.12 \mathrm{mM} \mathrm{N} \mathrm{L}^{-1}\right)$, indicating that this plant can perform well in substrates with high concentrations of ammonia. In addition, for aquaculture wastewater with concentrations equal to or greater than $4 \mathrm{mM} \mathrm{NH}_{4} \mathrm{Cl} \mathrm{L}^{-1}$ and up to $7.07 \pm 0.27 \mathrm{mM} \mathrm{N} \mathrm{g}^{-1} \mathrm{FW} \mathrm{h}^{-1}$, it is believed that the uptake rate does not increase because the plant blocks AMTs at higher concentrations. Concerning the kinetic characteristics of 
$\mathrm{N}$ uptake in plants, it has been proposed that species with higher maximum uptake rates might be better for cleaning up wastewater with high nutrient concentrations [46].

The cell wall plays an important role in stress perception by facilitating the activation of signaling pathways and remodeling growth strategies in response to stresses[47]. This structure constitutes the first line of defense against biotic and abiotic environmental influences through wall reinforcement via callose deposition [48]. In this study, enrichment analysis of DEGs under ammonium nutrition revealed that a set of overexpressed genes involved in secondary cell wall materials could contribute to the maintenance of cell wall structure and functional properties of S. neei. (Supplementary Fig. S3 and S4). Studies have reported that genes related to cell wall maintenance are significantly enriched in treatments that induce biotic or abiotic stress [49]. This is very interesting, as it has been shown that the cell wall structure is reassembled through the biosynthesis of cell wall polymers that allow it to adapt to stress conditions [47, 50,51]. Wang et al. [51] demonstrated that cell wall modifications were highly active in response to salt stress in cotton. The most common adaptations of the cell wall to stress include (i) increased levels of xyloglucan endotransglucosylase/hydrolase (XTH) and expansin proteins associated with an increase in the degree of rhamnogalacturonan I branching that maintains cell wall plasticity and (ii) increased cell wall thickening through reinforcement of the secondary wall with hemicellulose and lignin deposition [47, 52]. It was proposed that xyloglucan regulation by expansins could improve the efficiency of nutrient uptake. Several types of expansins respond to deficiencies in different nutrients, including nitrogen, phosphorus, potassium, and iron [53]. In this study, we found upregulated genes related to the xyloglucan metabolic process, cellular-glucan metabolic process, and cellular polysaccharide metabolic process categories (Supplementary Fig. S3) that can regulate several physiological plant responses through cell wall remodeling in S. neei.

Additionaly, we found several positively regulated genes encoding proteins involved in signaling that could potentially be induced in response to imposed ammonium treatment. Among the identified signaling genes are glutamate receptors 3.2, 3.3, 3.6-like (GLR3.3), (GLR3.3), and (GLR3.6), which suggests that glutamate (the precursor of proline, arginine, and ornithine) plays a role as a signaling molecule in response to environmental stress [54]. Although the function of GLRs is poorly understood, a recent study showed that GLR3 is involved in the response to salt stress in Arabidopsis [55]. We also found that GABA transporter 1, 2 (GAT1, GAT2) mediate the transport of $\psi$-aminobutyric acid (GABA), a non-protein amino acid that accumulates rapidly in 
plant tissues in response to biotic and abiotic stress. [56]. The overexpression of GABA transporters can increase the thickness of xylem cell walls in both Arabidopsis and poplar and enhance the lignin content of xylem tissues and the proline accumulation in poplar leaves, all of which may improve the salt/drought stress tolerance of desert poplars [57]. In addition it has been suggested that GABA can induce autophagy, which contributes to the recycling of damaged molecules and enhances stress tolerance [58].

KEGG analysis showed that DEGs were most enriched in biosynthesis of secondary metabolite this intracellular physiological defense responses help plants against environmental stresses indicating that they may likely play an important role in ammonium stress response, even though shoot only perceives $\mathrm{NH} 4+$ stress signals from the root indirectly [59]. studies indicate that The accumulation of secondary metabolite are highly dependent on environmental factors such as light, temperature, soil water, soil fertility, and salinity [60]. Another pathway observed in highly ammonium was amino acid biosynthesis this is the only reaction allowing assimilation of inorganic nitrogen into organic molecules and previous observation that $\mathrm{NH}_{4}{ }^{+}-\mathrm{N}$ is more efficient at promoting amino acid biosynthesis than $\mathrm{NO}_{3}{ }^{-}-\mathrm{N}[61]$.

Genes involved in transcription, consistent with the role of phytohormones as triggers of signal transduction cascades, are key components of responses to abiotic stress. We investigated the common and specific responses of $S$. neei shoots to ammonium stress, through upregulated or downregulated DEGs with special focus on rol of phytohormones, and we found abscisic acid (ABA) and ethylene two essential plant hormones regulating abiotic and biotic stresses $[62,63]$. According previous studies in some halophytes species under high salinity, ethylene production is increased in leaves and roots [64]. Similarly, it was observed that ABA and ET signaling pathways were increased under ammonium treatment in rice and maize $[23,59]$ suggesting that $E T$ and $A B A$ biosynthesis might increase in response to stress. Are known that these pathways interact among themselves at various nodes, such as hormone-responsive transcription factors to regulate plant defense response [65-67]. Among hormone pathways founded, ABA and ethylene biosynthesis genes were seen to be up-regulated under ammonium treatment in S. neei. In our study, ABA was in one pathway (Plant hormone signal transduction) and ethylene were in three pathways (Biosynthesis of secondary metabolite, plant hormone signal transduction and cysteine and methionine metabolism) in the top 10 KEGG (Table 3 and Table 4, and Supplementary Table. S3). 
We found S-AdoMet, SAM, ACC (direct precursor of the plant hormone ethylene) [68] (Fig. 7), centrally involves in ethylene biosynthesis and ZEP, VDE1, ABA2 involves in ABA biosynthesis. In addition, we found the key ABA responsive element binding factor and ethylene-responsive transcription factor. Therefore, we conclude that transduction pathway, regulated by $A B A$ and ethylene, have an important role in the stress response of S.neei to $\mathrm{NH}_{4}^{+}$.

The biosynthesis pathway of polyamines (PAs) and ethylene is interrelated, SAM being a common precursor and can be used to form ACC, the precursor of ethylene and in the conversion of PAs [69]. Their physiological functions are distinct and at times antagonistic [70], but at the same have been identified as important signaling molecules involved in stress tolerance [71]. In this study, overexpressed genes related to the metabolic pathways of polyamines were found (Table 4, Fig. 7, and Supplementary Table. S3). According to Navin et al. [60], putrescine, spermidine, and spermine biosynthesis are also involved in the amelioration of drought, salinity, cold, and heat stresses. Polyamines counter stress by binding with nucleic acids, proteins, and phospholipids to stabilize their structures in response to diverse abiotic stress conditions [60]. Bouchereau et al. [61] state that $\mathrm{NH}_{4}^{+}$nutrition is associated with significant changes in the free polyamine content in the shoots or roots of plants, which could be a key protective factor for the stressed cell [61]. We found, three genes PAO1, PAO2 and PAO4 encoding polyamine oxidase (PAO) which is an enzyme with distinct physiological roles and responsible for polyamine catabolism. In plants, increasing evidences support that PAO genes play essential roles in abiotic and biotic stresses response, some PAOs catalyze the reverse reaction of PA synthesis in the PA back-conversion pathway [72]. Tavladoraki et al. [73] identified PAO1 in Arabidopsis as an the enzyme which possesses back-conversion activity, responsible for the conversion of Spm to Spd. Similarly, Moschou el al.[74] identified In Arabidopsis, PAO1 and PAO4 were able to convert Spm to Spd; and PAO2 and PAO3 catalyzed the production of Spd from Spm and then produced Put. This result suggests involvement of PAO genes in stress response and probably have in implication of PA homeostasis in S. neei.

Considering the possible abiotic stress induced by ammonium-based nutrition, we looked for processes activated in the plant to avoid ammonium accumulation or mitigate its effects. Thus, a set of 61 upregulated and 12 downregulated genes related to nitrogen metabolism were found to be modulated by $\mathrm{NH}_{4}{ }^{+}$at salinity concentrations close to $600 \mathrm{mM} \mathrm{NaCl}$ in the shoots. Among the main genes recognized in the metabolism of $\mathrm{NH}_{4}^{+}$in plants, we propose a supposed route based 
on several upregulated genes like GS, GLT-1, 2-oxoglutarate dehydrogenase (2-OGD), ferredoxindependent glutamate synthase chloroplastic (Fd-GOGAT), and glutamate synthase 1 [NADH] chloroplastic isoform X1 (GLT1) (see Table 4, Fig. 7 and Supplementary Table. S3). Similar results have been published concerning the halophyte plant Salicornia europeae, which showed high GS and GDH activity at high salinity concentrations [30]. Further, Ma et al. [30] note that Salicornia plants fed with ammonia also need a salinity range of $200 \mathrm{mM} \mathrm{NaCl}$ or more in the substrate, conditions that presumably can stimulate the detoxification mechanisms generated by stress [75]. This could explain the ability of halophyte plants to thrive in environments where salinity is high and ammonia is a common nutrient. It had previously been revealed that some wetland plants and other marine species that grow in terrestrial habitats where $\mathrm{NH}_{4}^{+}$prevails over $\mathrm{NO}_{3}{ }^{-}$have a special preference for ammonia [76].

In plants, diverse abiotic stresses have been shown to induce autophagy, including nutrient starvation and oxidative stress, improving plant resistance [77]. The energy sensors SNF-related kinase 1 (SnRK1) and target of rapamycin (TOR) control autophagy under energy deficiency, but also under diverse stress conditions [58]. Signorelli et al [58], have suggested that accumulation of $\mathrm{GABA}, \mathrm{PA}$, ethylene and $\mathrm{ABA}$ under stress conditions can indirectly control autophagy too by different pathways.

Studies have theorized that additional cytosolic nutrients can be maintained by compartmentalizing them at sites where they are not metabolized, such as the vacuole [78, 79]. This direct encapsulation of nitrogen is possible through specialized autophagic vesicles that subsequently fuse with the vacuole for proteolysis and hydrolysis [80]. Moreover, materials such as nutrients can be remobilized to new growing organs and sinks such as seeds. in Arabidopsis, it was observed that autophagy can regulate abiotic stress caused by excessive uptake of toxic ions, the researchers reported that the level of autophagy peaks within 30 min after salt stress and then settles to a new homeostasis, such an induction is absent in mutants defective in autophagy [81]. In this transcriptome were found a series of autophagy-related genes (ATGs) are responsible for the initiation and formation of autophagosomes, for instance: ATG1/ATG13 kinase complex that initiates autophagosome formation; 2) the ATG9 forms a complex with accessary proteins ATG2 and ATG18, which promotes phagophore expansion and has been described as the only integral complex necessary for formation of the autophagosomal membrane [82]. 3) Complex for vesicle 
nucleation. 4) The ATG8/PE conjugates, which are located in both the inner and outer autophagosome membranes, aid phagophore expansion and vesicle closure to form autophagosomes and recognize autophagic cargoes through ATG8-interacting proteins [83]. This several genes related to autophagy were included in autophagy and other pathway. This vacuolar complex was probably induced to avoid apoplastic acidification that generates stress and leaf senescence $[28,84,85]$ (see Fig. 8).

\section{Conclusions}

The kinetics of ammonium uptake by Salicornia neei under ammonium nutrition has been characterized using the Michaelis-Menten equation. Our results support the hypothesis that S. neei is very effective at removing ammonium in concentrations $<4 \mathrm{mM}$, compared to other species used in aquaculture wastewater [7, 86]. The maximum rates (Imax) and the halfsaturation constants $(\mathrm{Km})$ for ammonium uptake were identified to demonstrate that $S$. neei can be used to treat effluent with ammonium pollutants. Salicornia neei showed a high affinity for substrate, which can be used to decontaminate waters with high nutrient loads from marine aquaculture.

The results propound that the ammonium detoxification system in S. neei is mediated by a wide variety of upregulated genes that are associated with the maintenance of ammonium homeostasis through the activation of glutamine and glutamate synthetase, accompanied by the biosynthesis of phytohormones and polyamines involved in the protection of important protein structures under stress conditions.

In S. neei, the vacuolar complex was probably induced to avoid apoplastic acidification induced by ammonium nutrition.

Cell wall biosynthesis possibly corresponds to the stress response induced by excess ammonia, taking into account that several studies related to stress response in plants have reported the biosynthesis of cell wall structures.

\section{Conflict of interests}

All authors declare that there are no present or potential conflicts of interest between the authors and other people or organizations that could inappropriately bias their work. 


\section{Financial support}

\section{GOBIERNO REGIONAL DE VALPARAÍSO, CHILE, grant number FIC BIP 30154272.}

\section{Acknowledgments}

The authors wish to thank Aldo Madrid and Marine Farms Inc. for their technical assistance and support during the project. M.R.D. was supported by a Doctoral fellowship from the "Dirección General de Investigación y Postgrado" of the Universidad Técnica Federico Santa María.

\section{References}

1. Diaz M, Javier A, Andrea O, Jaime O, Jose G: Efficiency of Salicornia neei to Treat Aquaculture Effluent from a Hypersaline and Artificial Wetland. Agriculture 2020:621

2. Alonso MA, Crespo MB: Taxonomic and nomenclatural notes on South American taxa of Sarcocornia (Chenopodiaceae). Annales Botanici Fennici 2008, 45(4):241-254.

3. Riquelme J, Olaeta JA, Galvez L, Undurraga P, Fuentealba C, Osses A, Orellana J, Gallardo J, Pedreschi R: Nutritional and functional characterization of wild and cultivated Sarcocornia neei grown in Chile. Ciencia $E$ Investigacion Agraria 2016, 43(2):283-293.

4. Alonso MF, Orellana C, Valdes S, Diaz FJ: Effect of salinity on the germination of Sarcocornia neei (Chenopodiaceae) from two contrasting habitats. Seed Science and Technology 2017, 45(1):252-258.

5. Boër B, elzturk M, Clüsener-Godt M, Gul B, Breckle SW: Sabkha Ecosystems: Volume V: The Americas, vol. V. Cham, Switzerland; 2016.

6. de Souza MM, Mendes CR, Doncato KB, Badiale-Furlong E, Costa CSB: Growth, Phenolics, Photosynthetic Pigments, and Antioxidant Response of Two New Genotypes of Sea Asparagus (Salicornia neei Lag.) to Salinity under Greenhouse and Field Conditions. Agriculture-Basel 2018, 8(7).

7. Quinta R, Santos R, Thomas DN, Le Vay L: Growth and nitrogen uptake by Salicornia europaea and Aster tripolium in nutrient conditions typical of aquaculture wastewater. Chemosphere 2015, 120:414-421.

8. Turcios AE, Papenbrock J: Sustainable Treatment of Aquaculture Effluents-What Can We Learn from the Past for the Future? Sustainability 2014, 6(2):836-856.

9. Islam MS: Nitrogen and phosphorus budget in coastal and marine cage aquaculture and impacts of effluent loading on ecosystem: review and analysis towards model development. Marine Pollution Bulletin 2005, 50(1):48-61.

10. Maillard VM, Boardman GD, Nyland JE, Kuhn DD: Water quality and sludge characterization at racewaysystem trout farms. Aquacultural Engineering 2005, 33(4):271-284.

11. Timmons MB, Ebeling JM, Wheaton FW, Summerfelt ST, Vinci BJ: Aquaculture water reuse systems, vol. 01002: Northeastern Regional Aquaculture Center Publication; 2002.

12. Bower CE, Bidwell JP: Ionization of ammonia in seawater: effects of temperature, $\mathrm{pH}$, and salinity. Journal of the Fisheries Board of Canada 1978, 35:1012-1016.

13. Carballeira C, De Orte MR, Viana IG, Carballeira A: Implementation of a minimal set of biological tests to assess the ecotoxic effects of effluents from land-based marine fish farms. Ecotoxicology and Environmental Safety 2012, 78:148-161.

14. Playchoom C, Pungrasmi W, Powtongsook S: Effect of Carbon Sources and Carbon/Nitrogen Ratio on Nitrate Removal in Aquaculture Denitrification Tank. In., vol. 1. Singapore: Environment and Chemistry; $2011: 307$ 311.

15. Shpigel M, Ben-Ezra D, Shauli L, Sagi M, Ventura Y, Samocha T, Lee JJ: Constructed wetland with Salicornia as a biofilter for mariculture effluents. Aquaculture 2013, 412:52-63.

16. Brown JJ, Glenn EP, Fitzsimmons KM, Smith SE: Halophytes for the treatment of saline aquaculture effluent. Aquaculture 1999, 175(3-4):255-268.

17. Cao L, Wang W, Yang Y, Yang C, Yuan Z, Xiong S, Diana J: Environmental impact of aquaculture and countermeasures to aquaculture pollution in China. Environmental Science and Pollution Research 2007, 14(7):452-462. 
18. Cloern JE: Our evolving conceptual model of the coastal eutrophication problem. Marine Ecology Progress Series 2001, 210:223-253.

19. Holmer M, Wildish D, Hargrave B: Organic enrichment from marine finfish aquaculture and effects on sediment biogeochemical processes. In: Environmental effects of marine finfish aquaculture. Springer; 2005: 181-206.

20. Hu Z, Lee JW, Chandran K, Kim S, Brotto AC, Khanal SK: Effect of plant species on nitrogen recovery in aquaponics. Bioresource Technology 2015, 188:92-98.

21. Meade JW: Allowable ammonia for fish culture. Progressive Fish-Culturist 1985, 47(3):135-145.

22. Waller U, Buhmann AK, Ernst A, Hanke V, Kulakowski A, Wecker B, Orellana J, Papenbrock J: Integrated multitrophic aquaculture in a zero-exchange recirculation aquaculture system for marine fish and hydroponic halophyte production. Aquaculture International 2015, 23(6):1473-1489.

23. Ravazzolo L, Trevisan S, Forestan C, Varotto S, Sut S, Dall'Acqua S, Malagoli M, Quaggiotti S: Nitrate and Ammonium Affect the Overall Maize Response to Nitrogen Availability by Triggering Specific and Common Transcriptional Signatures in Roots. International Journal of Molecular Sciences 2020, 21(2).

24. Coleto I, Bejarano I, Marín-Peña AJ, Medina J, Rioja C, Burow M, Marino D: Arabidopsis thaliana transcription factors MYB28 and MYB29 shape ammonium stress responses by regulating Fe homeostasis.

25. Britto DT, Kronzucker HJ: NH4+ toxicity in higher plants: a critical review. Journal of Plant Physiology 2002, 159(6):567-584.

26. Tang ZH, Liu YJ, Guo XR, Zu YG: The combined effects of salinity and nitrogen forms on Catharanthus roseus: The role of internal ammonium and free amino acids during salt stress. Journal of Plant Nutrition and Soil Science 2011, 174(1):135-144.

27. Cruz C, Bio AFM, Dominguez-Valdivia MD, Aparicio-Tejo PM, Lamsfus C, Martins-Loucao MA: How does glutamine synthetase activity determine plant tolerance to ammonium? Planta 2006, 223(5):1068-1080.

28. Liu Y, von Wiren N: Ammonium as a signal for physiological and morphological responses in plants. Journal of Experimental Botany 2017, 68(10):2581-2592.

29. Meng $X Q$, Zhou J, Sui N: Mechanisms of salt tolerance in halophytes: current understanding and recent advances. Open Life Sciences 2018, 13(1):149-154.

30. Ma JB, Cirillo V, Zhang DY, Maggio A, Wang L, Xiao XL, Yao YN: Regulation of Ammonium Cellular Levels is An Important Adaptive Trait for the Euhalophytic Behavior of Salicornia europaea. Plants-Basel 2020, 9(2).

31. Ashraf M, Shahzad SM, Imtiaz M, Rizwan MS: Salinity effects on nitrogen metabolism in plants - focusing on the activities of nitrogen metabolizing enzymes: A review. Journal of Plant Nutrition 2018, 41(8):1065-1081.

32. Stewart GR, Rhodes D: Nitrogen-metabolism of halophytes .3. enzymes of ammonia assimilation. New Phytologist 1978, 80(2):307-316.

33. Gutierez RA, Stokes TL, Thum K, Xu X, Obertello M, Katari MS, Tanurdzic M, Dean A, Nero DC, McClung CR et al: Systems approach identifies an organic nitrogen-responsive gene network that is regulated by the master clock control gene CCA1. Proceedings of the National Academy of Sciences of the United States of America 2008, 105(12):4939-4944.

34. Yokoishi T, Tanimoto S: Seed-germination of the halophyte suaeda-japonica under salt stress. Journal of Plant Research 1994, 107(1088):385-388.

35. Kumari A, Das P, Parida AK, Agarwal PK: Proteomics, metabolomics, and ionomics perspectives of salinity tolerance in halophytes. Frontiers in Plant Science 2015, 6.

36. Crosby NT: Determination of ammonia by the Nessler method in waters containing hydrazine. Analyst 1968 93(1107):406-408.

37. Adamowicz S, Le Bot J: Trends in modelling nitrate uptake. Acta Hortic 1999:231-240.

38. Chang S, Puryear J, Cairney JA: A simple and efficient method for isolating RNA from pine trees. Plant Molecular Biology Reporter 1993(11):113-116.

39. Lal L, Sahoo R, Gupta R: RNA isolation from high phenolic tea leaves and buds. Plant molecular biology report 2001, 19:181.

40. Meisel L, Fonseca B, Gonzalez S, Baeza-Yates R, Cambiazo V, Campos R, Gonzalez M, Orellana A, Retamales J, Silva $H$ : A rapid and efficient method for purifying high quality total RNA from peaches (Prunus persica) for functional genomics analyses. Biological Research 2005, 38(1):83-88.

41. Camacho C, Coulouris G, Avagyan V, Ma N, Papadopoulos J, Bealer K, Madden TL: BLAST plus : architecture and applications. Bmc Bioinformatics 2009, 10.

42. Conesa A, Gotz S, Garcia-Gomez JM, Terol J, Talon M, Robles M: Blast2GO: a universal tool for annotation, visualization and analysis in functional genomics research. Bioinformatics 2005, 21(18):3674-3676.

43. Kal AJ, van Zonneveld AJ, Benes V, van den Berg M, Koerkamp MG, Albermann K, Strack N, Ruijter JM, Richter $A$, Dujon B et al: Dynamics of gene expression revealed by comparison of serial analysis of gene expression transcript profiles from yeast grown on two different carbon sources. Molecular Biology of the Cell 1999, 10(6):1859-1872. 
44. Bolstad BM, Irizarry RA, Astrand M, Speed TP: A comparison of normalization methods for high density oligonucleotide array data based on variance and bias. Bioinformatics 2003, 19(2):185-193.

45. Hu JN, Liu JN, Fan JL, Hu Z, Xie HJ, Wang SN, Liu JH: Effect of salinity on the performance of constructed wetlands treating mariculture wastewater with different halophytes and its molecular biological mechanism. Desalination and Water Treatment 2017, 99:255-265.

46. Wang L, Yao WJ, Sun Y, Wang JY, Jiang TB: Association of transcription factor WRKY56 gene from Populus simonii x P. nigra with salt tolerance in Arabidopsis thaliana. Peerj 2019, 7.

47. Gall HL, Philippe F, Domon J-M, Gillet F, Pelloux J, Rayon C: Cell Wall Metabolism in Response to Abiotic Stress. Plants (Basel) 2015, 4(1):112-166.

48. Kesten C, Menna A, Sanchez-Rodriguez C: Regulation of cellulose synthesis in response to stress. Current Opinion in Plant Biology 2017, 40:106-113.

49. Tenhaken R: Cell wall remodeling under abiotic stress. Frontiers in Plant Science 2015, 5.

50. Walia H, Wilson C, Condamine P, Liu X, Ismail AM, Zeng LH, Wanamaker SI, Mandal J, Xu J, Cui XP et al: Comparative transcriptional profiling of two contrasting rice genotypes under salinity stress during the vegetative growth stage. Plant Physiology 2005, 139(2):822-835.

51. Wang DL, Lu XK, Chen XG, Wang S, Wang JJ, Guo LX, Yin ZJ, Chen QJ, Ye WW: Temporal salt stress-induced transcriptome alterations and regulatory mechanisms revealed by PacBio long-reads RNA sequencing in Gossypium hirsutum. Bmc Genomics 2020, 21(1).

52. Jiao PP, Wu ZH, Wang X, Jiang ZB, Wang YQ, Liu H, Qin R, Li ZJ: Short-term transcriptomic responses of Populus euphratica roots and leaves to drought stress. Journal of Forestry Research.

53. Li XX, Zhao J, Walk TC, Liao H: Characterization of soybean beta-expansin genes and their expression responses to symbiosis, nutrient deficiency, and hormone treatment. Applied Microbiology and Biotechnology 2014, 98(6):2805-2817.

54. Lam HM, Chiu J, Hsieh MH, Meisel L, Oliveira IC, Shin M, Coruzzi G: Glutamate-receptor genes in plants. Nature 1998, 396(6707):125-126.

55. Wang PH, Lee CE, Lin YS, Lee MH, Chen PY, Chang HC, Chang IF: The Glutamate Receptor-Like Protein GLR3.7 Interacts With 14-3-3 omega and Participates in Salt Stress Response in Arabidopsis thaliana. Frontiers in Plant Science 2019, 10.

56. Ramos-Ruiz R, Poirot E, Flores-Mosquera M: GABA, a non-protein amino acid ubiquitous in food matrices. Cogent Food \& Agriculture 2018, 4(1).

57. Bai XT, Xu JM, Shao XM, Luo WC, Niu ZM, Gao CY, Wan DS: A Novel Gene Coding gamma-Aminobutyric Acid Transporter May Improve the Tolerance of Populus euphratica to Adverse Environments. Frontiers in Plant Science 2019, 10.

58. Signorelli S, Tarkowski LP, Van den Ende W, Bassham DC: Linking Autophagy to Abiotic and Biotic Stress Responses. Trends in Plant Science 2019, 24(5):413-430.

59. Sun L, Di DW, Li GJ, Kronzucker HJ, Shi WM: Spatio-temporal dynamics in global rice gene expression (Oryza sativa L.) in response to high ammonium stress. Journal of Plant Physiology 2017, 212:94-104.

60. Jan R, Asaf S, Numan M, Lubna, Kim KM: Plant Secondary Metabolite Biosynthesis and Transcriptional Regulation in Response to Biotic and Abiotic Stress Conditions. Agronomy-Base/ 2021, 11(5).

61. Yang YY, Li XH, Ratcliffe RG, Ruan JY: Characterization of ammonium and nitrate uptake and assimilation in roots of tea plants. Russian Journal of Plant Physiology 2013, 60(1):91-99.

62. Binder BM: Ethylene signaling in plants. Journal of Biological Chemistry 2020, 295(22):7710-7725.

63. Chen K, Li GJ, Bressan RA, Song CP, Zhu JK, Zhao Y: Abscisic acid dynamics, signaling, and functions in plants. Journal of Integrative Plant Biology 2020, 62(1):25-54.

64. Ellouzi H, Ben Hamed K, Hernandez I, Cela J, Muller M, Magne C, Abdelly C, Munne-Bosch S: A comparative study of the early osmotic, ionic, redox and hormonal signaling response in leaves and roots of two halophytes and a glycophyte to salinity. Planta 2014, 240(6):1299-1317.

65. Verma V, Ravindran P, Kumar PP: Plant hormone-mediated regulation of stress responses. Bmc Plant Biology 2016, 16.

66. Li ZF, Zhang LX, Yu YW, Quan RD, Zhang ZJ, Zhang HW, Huang RF: The ethylene response factor AtERF11 that is transcriptionally modulated by the bZIP transcription factor HY5 is a crucial repressor for ethylene biosynthesis in Arabidopsis. Plant Journal 2011, 68(1):88-99.

67. Madhavan S, Chrominiski A, Smith BN: Effect of ethylene on stomatal opening in tomato and carnation leaves. Plant and Cell Physiology 1983, 24(3):569-572.

68. Polko JK, Kieber JJ: 1-Aminocyclopropane 1-Carboxylic Acid and Its Emerging Role as an EthyleneIndependent Growth Regulator. Frontiers in Plant Science 2019, 10.

69. Zapata PJ, Serrano M, Garcia-Legaz MF, Pretel MT, Botella MA: Short Term Effect of Salt Shock on Ethylene and Polyamines Depends on Plant Salt Sensitivity. Frontiers in Plant Science 2017, 8. 
70. Pandey S, Ranade SA, Nagar PK, Kumar N: Role of polyamines and ethylene as modulators of plant senescence. Journal of Biosciences 2000, 25(3):291-299.

71. Gupta K, Dey A, Gupta B: Plant polyamines in abiotic stress responses. Acta Physiologiae Plantarum 2013, 35(7):2015-2036.

72. Liu Q, Nishibori N, Imai I, Hollibaugh JT: Response of polyamine pools in marine phytoplankton to nutrient limitation and variation in temperature and salinity. Marine Ecology Progress Series 2016, 544:93-105.

73. Tavladoraki P, Rossi MN, Saccuti G, Perez-Amador MA, Polticelli F, Angelini R, Federico R: Heterologous expression and biochemical characterization of a polyamine oxidase from Arabidopsis involved in polyamine back conversion. Plant Physiology 2006, 141(4):1519-1532.

74. PN M, KA P, KA R-A: Plant polyamine catabolism: The state of the art. Plant Signal Behav 2008, 3(12):10611066.

75. Flowers TJ, Colmer TD: Plant salt tolerance: adaptations in halophytes. Annals of Botany 2015, 115(3):327331.

76. Thursby GB, Harlin MM: Interaction of leaves and roots of ruppia-maritima in the uptake of phosphate, ammonia and nitrate. Marine Biology 1984, 83(1):61-67.

77. Liu YM, Xiong Y, Bassham DC: Autophagy is required for tolerance of drought and salt stress in plants. Autophagy 2009, 5(7):954-963.

78. Howitt SM, Udvardi MK: Structure, function and regulation of ammonium transporters in plants. Biochimica Et Biophysica Acta-Biomembranes 2000, 1465(1-2):152-170.

79. Martinoia E, Maeshima M, Neuhaus HE: Vacuolar transporters and their essential role in plant metabolism. Journal of Experimental Botany 2007, 58(1):83-102.

80. Chen QW, Shinozaki D, Luo J, Pottier M, Have M, Marmagne A, Reisdorf-Cren M, Chardon F, Thomine S, Yoshimoto Ket al: Autophagy and Nutrients Management in Plants. Cells 2019, 8(11).

81. Luo LM, Zhang PP, Zhu RH, Fu J, Su J, Zheng J, Wang ZY, Wang D, Gong QQ: Autophagy Is Rapidly Induced by Salt Stress and Is Required for Salt Tolerance in Arabidopsis. Frontiers in Plant Science 2017, 8.

82. He CC, Klionsky DJ: Atg9 trafficking in autophagy-related pathways. Autophagy 2007, 3(3):271-274.

83. Johansen T, Lamark T: Selective autophagy mediated by autophagic adapter proteins. Autophagy 2011, 7(3):279-296.

84. Marino D, Moran JF: Can Ammonium Stress Be Positive for Plant Performance? Frontiers in Plant Science 2019, 10.

85. Patterson K, Cakmak T, Cooper A, Lager I, Rasmusson AG, Escobar MA: Distinct signalling pathways and transcriptome response signatures differentiate ammonium- and nitrate-supplied plants. Plant Cell and Environment 2010, 33(9):1486-1501.

86. Yao F, Sun J, Tang C, Ni W: Kinetics of Ammonium, Nitrate and Phosphate Uptake by Candidate Plants Used in Constructed Wetlands. Procedia Environmental Sciences 2011:1854-1861. 
Table 1. Summary of RNA-seq and de novo sequence assembly for Salicornia neei.

\begin{tabular}{cccc}
\hline & Count & Average length (bp) & Total bases (bp) \\
\hline Reads & $14,680,108$ & 170 & $1,482,690,908$ \\
Matched & $13,106,972$ & 101 & $1,323,804,172$ \\
Raw contigs & 129,772 & 586 & $76,046,392$ \\
Contigs & 86,020 & 586 & $56,452,896$ \\
\hline
\end{tabular}

Table 2. Summary of annotations of assembled Salicornia neei contigs.

\begin{tabular}{ccc}
\hline Database & $\begin{array}{c}\text { Number of } \\
\text { contigs annotated }\end{array}$ & $\begin{array}{c}\text { Percentage of } \\
\text { contigs annotated }\end{array}$ \\
\hline NCBI (NR) & 45,327 & 52.6 \\
\hline NCBI (NT Salicornia) & 32,609 & 37.9 \\
COG & 20,047 & 23.3 \\
GO & 37,784 & 43.9 \\
KEGG & 13,604 & 15.8 \\
\hline
\end{tabular}

COG: Clusters of Orthologous Groups; GO: Gene Ontology; KEGG: Encyclopedia of Genes and Genomes.

Table 3. Summary of distribution of Kyoto Encyclopedia of Genes and Genomes (KEGG) pathways in the $S$. neei transcriptome (top ten de rutas con mayor numero de contigs asociados).

\begin{tabular}{ccc}
\hline Pathway & $\begin{array}{c}\text { KEGG } \\
\text { Pathway }\end{array}$ & $\mathbf{N}^{\circ}$ Contigs \\
\hline Biosynthesis of secondary metabolite & map01110 & 297 \\
Biosynthesis of antibiotics & map01130 & 95 \\
\hline Amino acid biosynthesis & Map01230 & 71 \\
\hline Carbon metabolism & map01200 & 61 \\
\hline Starch and sucrose metabolism & map00500 & 55 \\
\hline Plant hormone signal transduction & map04075 & 53 \\
\hline Phenylpropanoid biosynthesis & map00940 & 52 \\
\hline Cysteine and methionine metabolism & map00270 & 34 \\
\hline Arginine and proline metabolism & map00330 & 28 \\
\hline Purine metabolism & Map00230 & 21 \\
\hline Nitrogen metabolism & map00910 & 25 \\
Autophagy - other & map04136 & 20 \\
\hline
\end{tabular}


Table 4. Genes involved in ammonium homeostasis and phytohormone biosynthesis in Salicornia neei.

\begin{tabular}{|c|c|c|c|c|}
\hline Classification & NCBI Accession & $\begin{array}{l}\text { Differentially expressed } \\
\text { protein-coding genes }\end{array}$ & Role & $\begin{array}{l}\text { Log2-fold } \\
\text { change }\end{array}$ \\
\hline \multirow{6}{*}{$\begin{array}{l}\text { genes related } \\
\text { to nitrogen } \\
\text { metabolism }\end{array}$} & GHTP01016006.1 & $\begin{array}{l}\text { glutamine synthetase } \\
\text { (GLN1) }\end{array}$ & $\begin{array}{l}\text { Plays an essential role } \\
\text { in the metabolism of } \\
\text { nitrogen by catalyzing } \\
\text { the condensation of } \\
\text { glutamate and } \\
\text { ammonia to form } \\
\text { glutamine }\end{array}$ & 100,000 \\
\hline & GHTP01002667.1 & $\begin{array}{c}\text { ammonium transporter } 3 \\
\text { member 1-like (AMT3.1) }\end{array}$ & $\begin{array}{l}\text { Involved in ammonium } \\
\text { transport }\end{array}$ & 7.75 \\
\hline & GHTP01006207.1 & $\begin{array}{l}\text { pyrroline-5-carboxylate } \\
\text { synthetase (P5CS) }\end{array}$ & $\begin{array}{l}\text { Plays a key role in } \\
\text { proline biosynthesis, } \\
\text { leading to } \\
\text { osmoregulation in } \\
\text { plants }\end{array}$ & 5.68 \\
\hline & GHTP01009881.1 & $\begin{array}{l}\text { glutamate synthase } 1 \\
\text { [NADH] chloroplastic } \\
\text { isoform X1 (GS) }\end{array}$ & $\begin{array}{l}\text { Catalyzes reactions } \\
\text { that convert } \alpha \text { - } \\
\text { ketoglutarate and } \\
\text { ammonia to glutamate, } \\
\text { which is then used in a } \\
\text { wide variety of } \\
\text { biosynthetic reactions }\end{array}$ & 5.19 \\
\hline & GHTP01037737.1 & $\begin{array}{l}\text { ferredoxin-dependent } \\
\text { glutamate synthase } \\
\text { chloroplastic (Fd-GOGAT) }\end{array}$ & $\begin{array}{l}\text { Has a primary role in } \\
\text { photosynthetic tissues }\end{array}$ & 4.29 \\
\hline & GHTP01000190.1 & $\begin{array}{l}\text { high affinity nitrate } \\
\text { transporter } 2.5 \text {-like } \\
\text { (NRT2.5) }\end{array}$ & $\begin{array}{c}\text { Might be involved in } \\
\text { the transfer of nitrate } \\
\text { from stored pools to } \\
\text { cytoplasm }\end{array}$ & 4.18 \\
\hline \multirow{4}{*}{$\begin{array}{l}\text { genes related } \\
\text { to polyamines }\end{array}$} & GHTP01019462.1 & $\begin{array}{l}\text { arginine decarboxylase } \\
\text { (ADC) }\end{array}$ & $\begin{array}{l}\text { Important enzyme } \\
\text { responsible for } \\
\text { putrescine biosynthesis }\end{array}$ & 2.36 \\
\hline & GHTP01012076.1 & $\begin{array}{l}\text { S-adenosylmethionine } \\
\text { decarboxylase } \\
\text { (SAM) }\end{array}$ & $\begin{array}{l}\text { Key enzyme in higher } \\
\text { polyamine (PA) } \\
\text { biosynthesis }\end{array}$ & 2.25 \\
\hline & GHTP01012076.1 & $\begin{array}{c}\text { adenosylmethionine } \\
\text { decarboxylase proenzyme } \\
\text { (SAMDC1) }\end{array}$ & $\begin{array}{l}\text { Plays an essential } \\
\text { regulatory role in the } \\
\text { polyamine biosynthetic } \\
\text { pathway }\end{array}$ & 2.25 \\
\hline & GHTP01019486.1 & $\begin{array}{c}\text { polyamine oxidase } 1 \\
\text { (PAO1) }\end{array}$ & $\begin{array}{l}\text { Involved in the } \\
\text { production of } \\
\text { hydrogen peroxide in } \\
\text { response to salt and } \\
\text { cold stresses }\end{array}$ & 2.04 \\
\hline
\end{tabular}




\begin{tabular}{|c|c|c|c|c|}
\hline \multirow{3}{*}{$\begin{array}{c}\text { genes related } \\
\text { to ethylene } \\
\text { biosynthesis }\end{array}$} & GHTP01022642.1 & $\begin{array}{c}\text { ethylene-responsive } \\
\text { transcription factor like } \\
\text { (ERF109) }\end{array}$ & $\begin{array}{l}\text { May be involved in the } \\
\text { regulation of gene } \\
\text { expression by stress } \\
\text { factors and by } \\
\text { components of stress } \\
\text { signal transduction } \\
\text { pathways }\end{array}$ & 100,000 \\
\hline & GHTP01023420.1 & $\begin{array}{l}\text { ethylene-insensitive } \\
\text { protein } 2 \text { isoform X1 } \\
\text { (EIN2) }\end{array}$ & $\begin{array}{l}\text { Might take part in } \\
\text { multiple hormone } \\
\text { signaling pathways and } \\
\text { in response to } \\
\text { pathogens as } \\
\text { demonstrated by } \\
\text { recent genetic and } \\
\text { biochemical studies }\end{array}$ & 2.39 \\
\hline & GHTP01045464.1 & $\begin{array}{l}\text { heat stress transcription } \\
\text { factor A-3 (HsfA3) }\end{array}$ & $\begin{array}{l}\text { Conferring salt } \\
\text { tolerance }\end{array}$ & 4.93 \\
\hline \multirow[t]{2}{*}{$\begin{array}{l}\text { genes related } \\
\text { to } A B A \\
\text { biosynthesis }\end{array}$} & GHTP01059070.1 & $\begin{array}{c}\text { ABA responsive element } \\
\text { binding factor }\end{array}$ & $\begin{array}{l}\text { Transcription factors } \\
\text { that regulate } \\
\text { expression of target } \\
\text { genes involved in plant } \\
\text { tolerance to drought, } \\
\text { high salinity, and } \\
\text { osmotic stress }\end{array}$ & 4.2 \\
\hline & GHTP01022623.1 & $\begin{array}{l}\text { dehydration-responsive } \\
\text { element-binding protein } \\
\text { (DREB2A) }\end{array}$ & $\begin{array}{l}\text { Plays a critical role in } \\
\text { plant development and } \\
\text { abiotic stress-mediated } \\
\text { gene expression }\end{array}$ & 2.05 \\
\hline
\end{tabular}


bioRxiv preprint doi: https://doi.org/10.1101/2021.09.07.458783; this version posted September 8, 2021. The copyright holder for this preprint (which was not certified by peer review) is the author/funder, who has granted bioRxiv a license to display the preprint in perpetuity. It is made available under aCC-BY-NC-ND 4.0 International license.
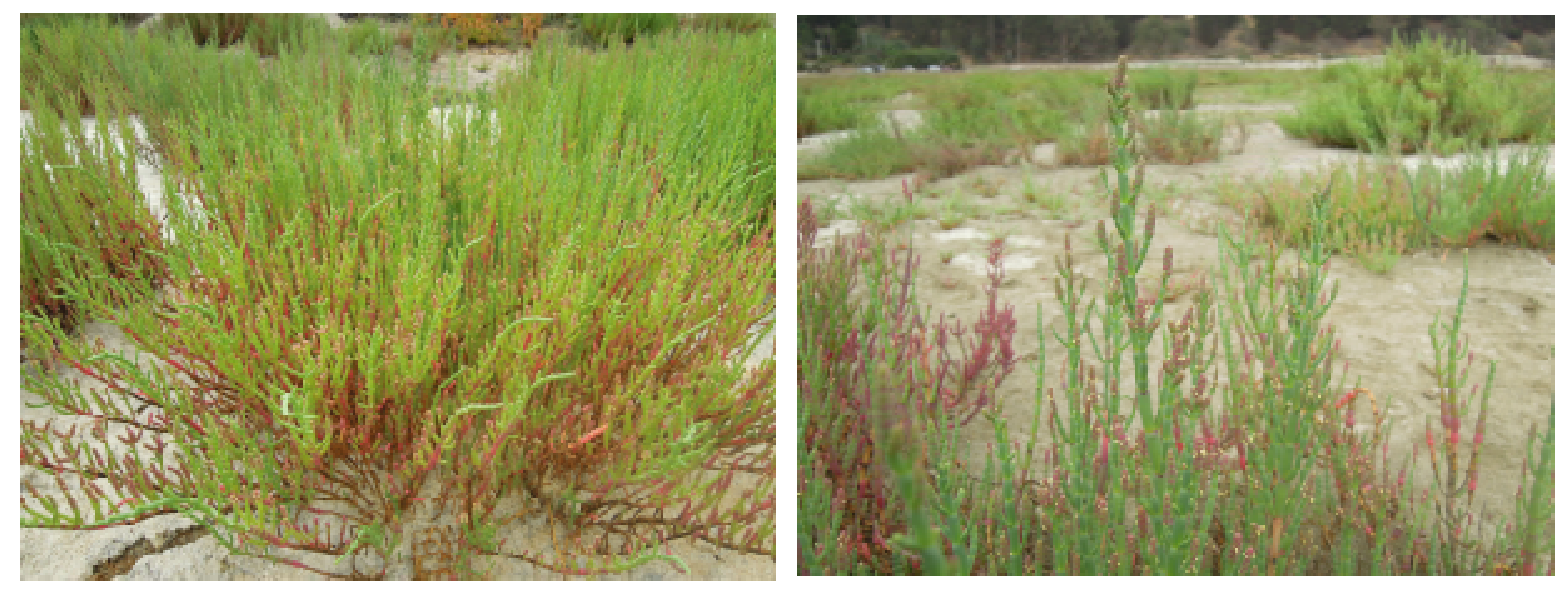

Fig. 1. Salicornia neei wild plants from "Pullally" salt marsh (Papudo, Chile; latitude, $32^{\circ} 24^{\prime} 50^{\prime \prime S}$; longitude, $71^{\circ} 23^{\prime} 35.01^{\prime \prime} \mathrm{W}$ ). 
bioRxiv preprint doi: https://doi.org/10.1101/2021.09.07 458783: this version posted September 8 , 2021. The copyright holder for this preprint (which was not certified by peer review) is the author/funder, who has granted bioRxiv a license to display the preprint in perpetuity. It is made available under aCC-BY-NC-ND 4.0 International license.

\section{Michaelis-Menten kinetics}

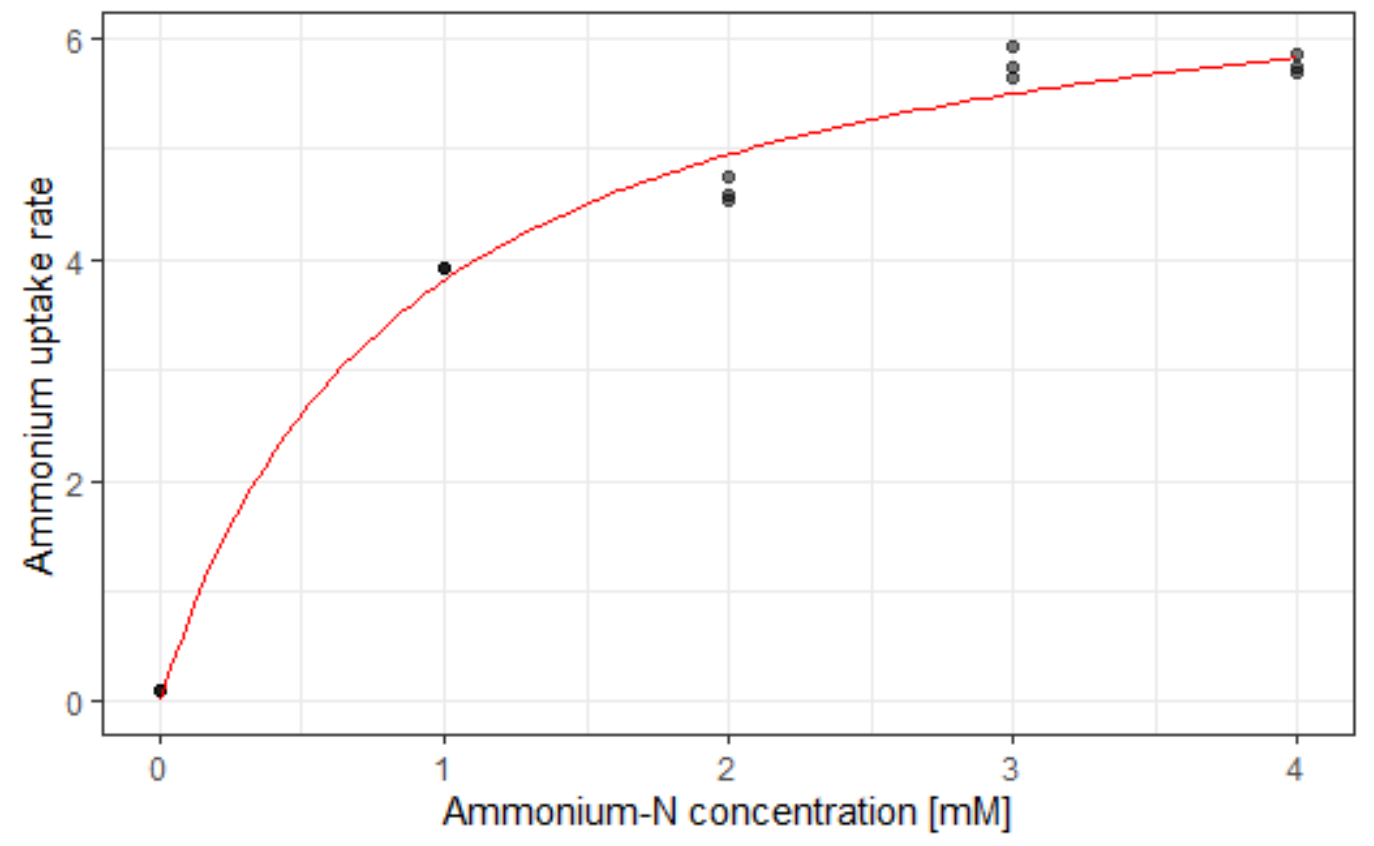

Fig. 2. S. neei ammonium uptake rate as a function of ammonium concentration. 


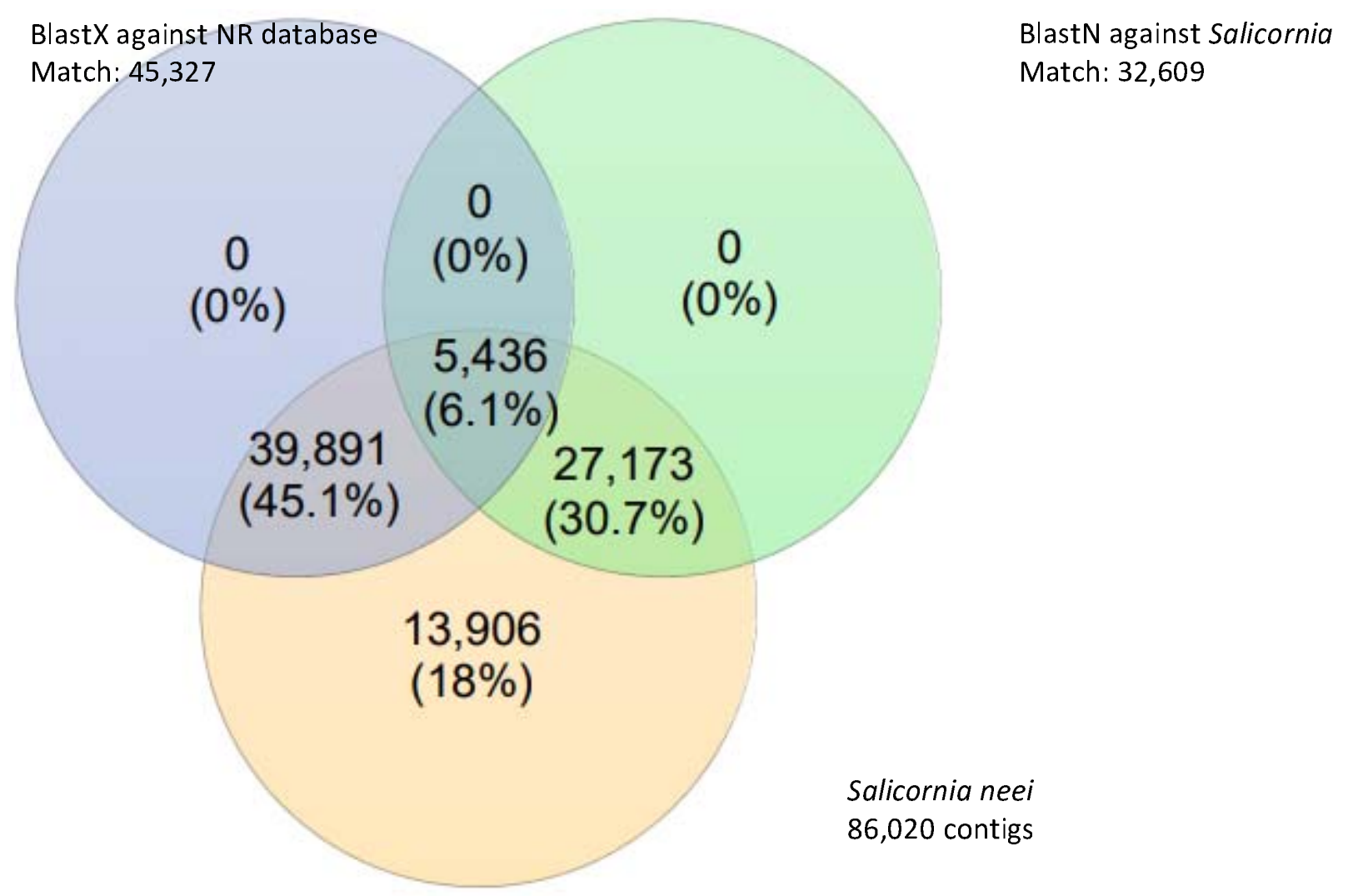

Fig. 3. Venn diagram of contigs annotated of $S$. neei with significant blast hits against NR database (blue), NT - Salicornia sequences (green) and new sequences from S. neei that did not match with other databases (orange). 


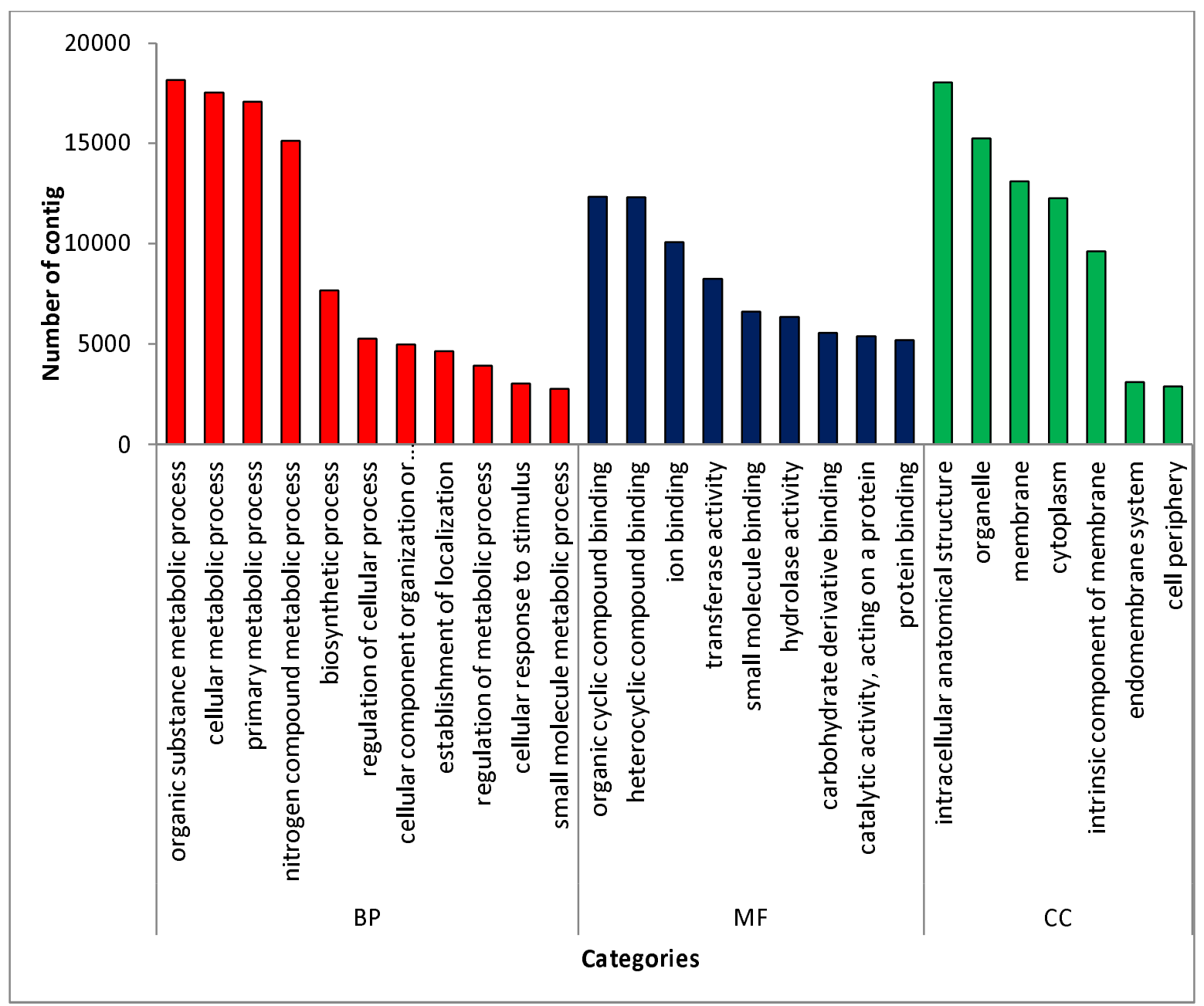

Fig. 4. Histogram of Gene Ontology (GO) classification of 37,784 S. neei transcripts assigned to three main categories: biological process (BP), molecular function MF) and cellular component (CC). 
bioRxiv preprint doi: https://doi.org/10.1101/2021.09.07.458783; this version posted September 8, 2021. The copyright holder for this preprint (which was not certified by peer review) is the author/funder, who has granted bioRxiv a license to display the preprint in perpetuity. It is made available under aCC-BY-NC-ND 4.0 International license.

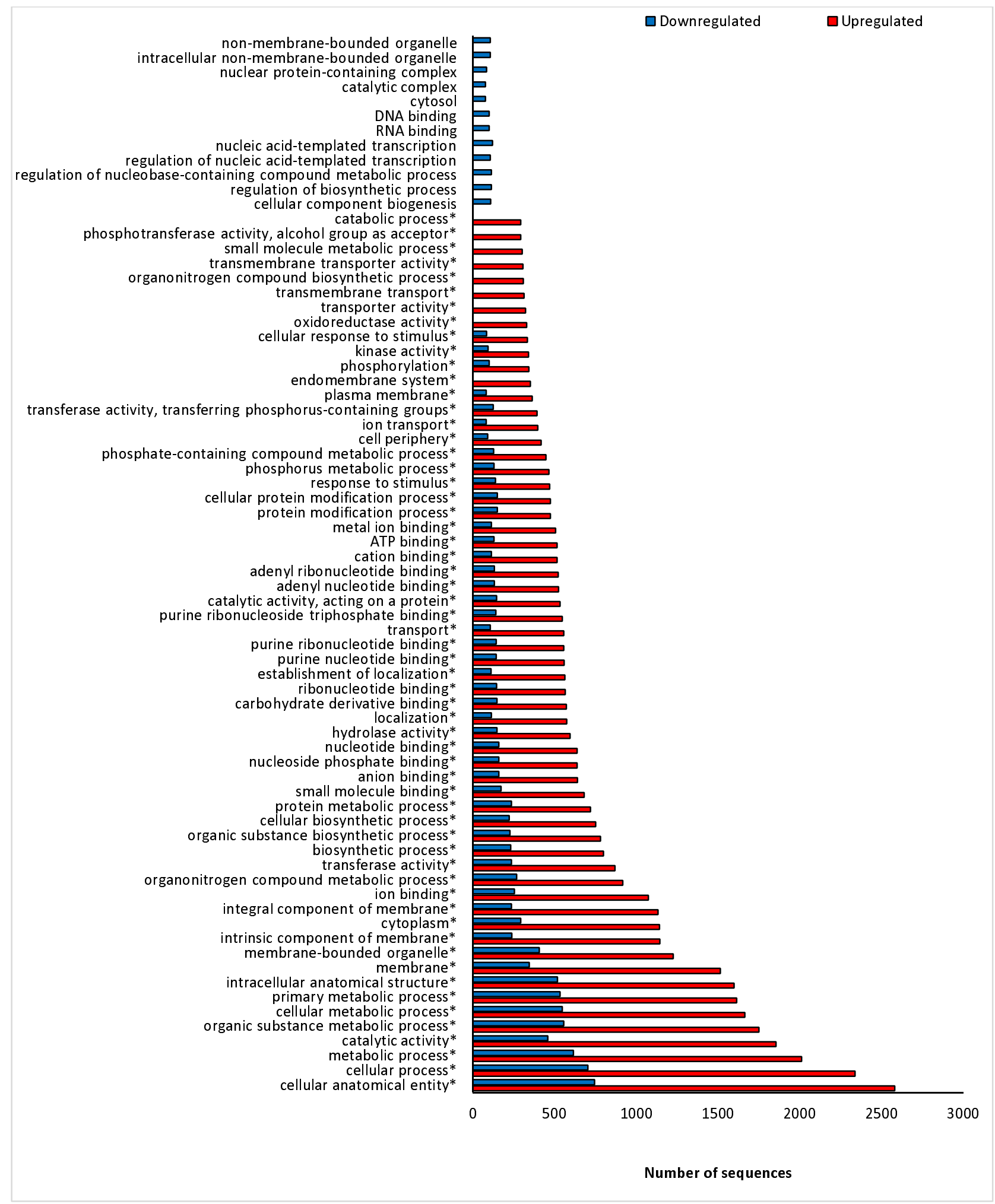

Fig. 5. Histogram of Gene Ontology (GO) classification of 4,850 DEG in S. neei transcripts upregulated with 0 and $3 \mathrm{mM}$ of ammonium. Asterisk $\left({ }^{*}\right)$ indicates three times more transcripts upregulated at $3 \mathrm{mM}$ ammonium compared to $0 \mathrm{mM}$ ammonium. 
bioRxiv preprint doi: https://doi.org/10.1101/2021.09.07.458783; this version posted September 8, 2021. The copyright holder for this preprint (which was not certified by peer review) is the author/funder, who has granted bioRxiv a license to display the preprint in perpetuity. It is made available under aCC-BY-NC-ND 4.0 International license.

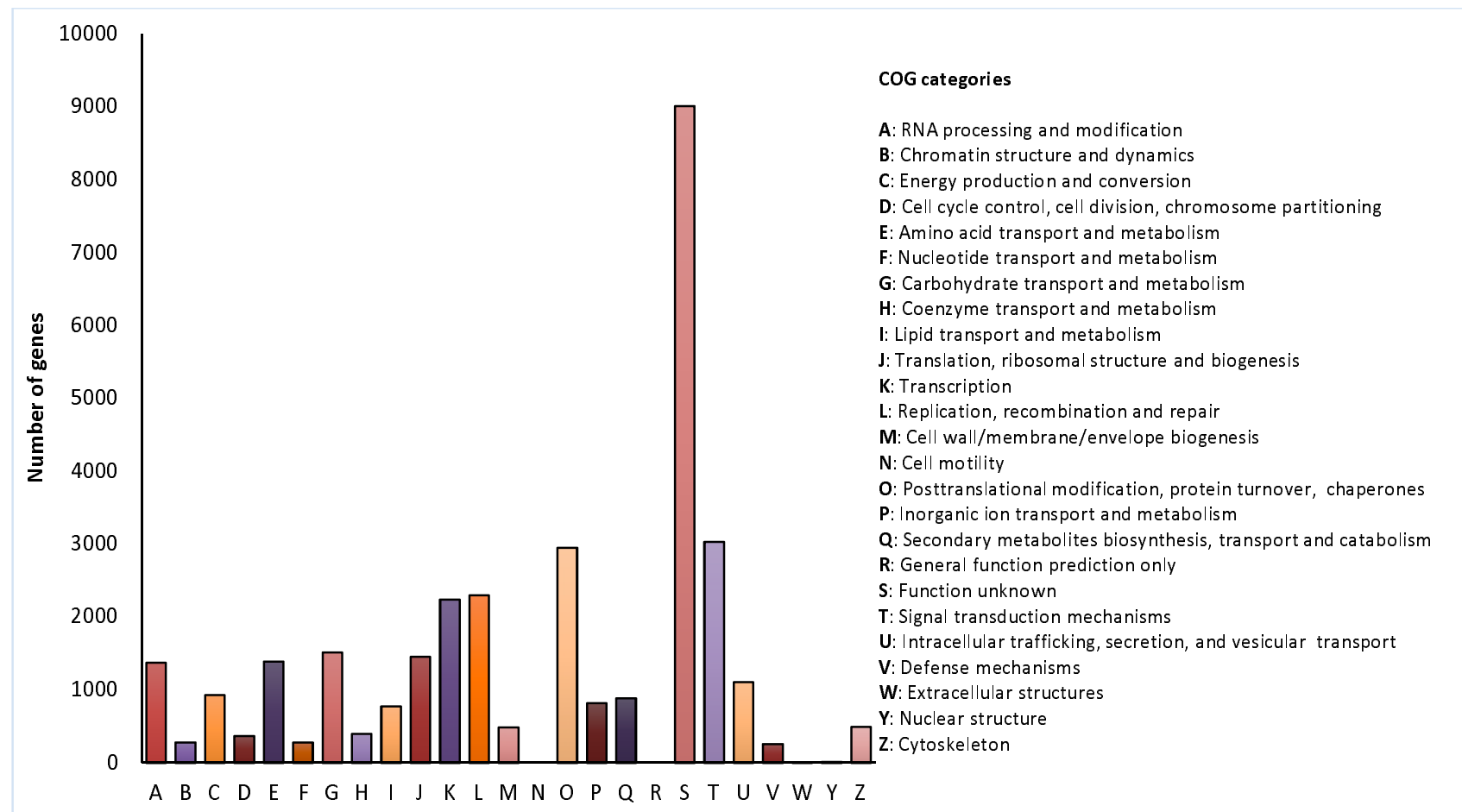

Fig. 6. Histogram of the COG classification. A total of 20,047 Salicornia neei contigs were assigned to one or more COG functional categories. The letters on the $x$-axis represent different COG categories. The $y$-axis represents the number of contigs participating in different COG categories. 


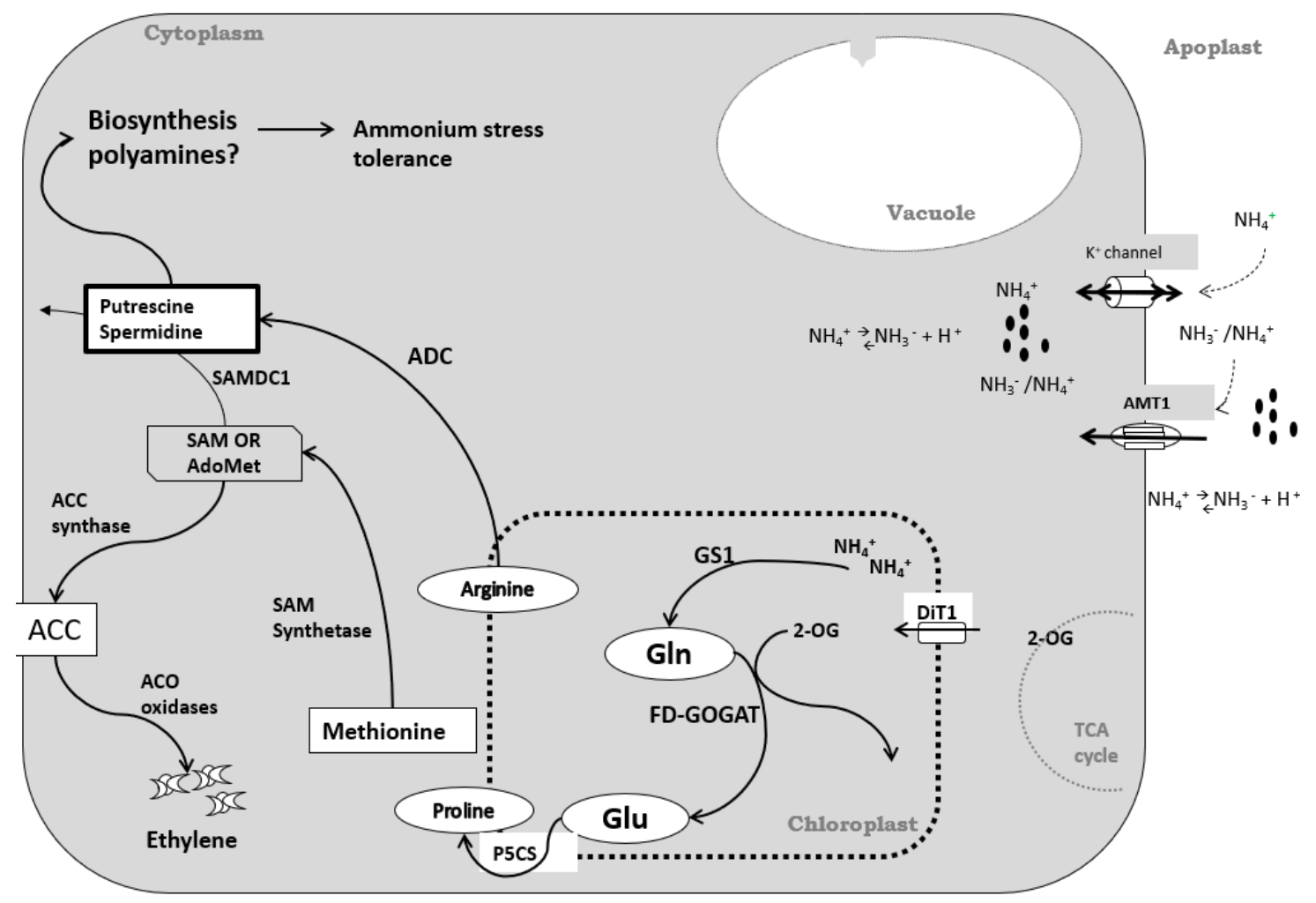

Fig. 7. Putative model of ammonium metabolism in Salicornia neei, polyamines and ethylene biosynthesis, according to the major DEGs that were modulated by $\mathrm{NH}_{4}^{+}$: ammonium transporter 1 (AMT1), glutamine synthetase 1 (GS1), ferredoxin-dependent glutamate synthase (Fd-GOGAT), glutamate (Glu), glutamine (Gln), pyrroline-5-carboxylate synthetase (P5CS), 2-oxoglutarate (2OG), dicarboxylate transporter 1 (DiT1), arginine decarboxylase (ADC), S-adenosylmethionine decarboxylase (SAMDC1), tricarboxylic acid cycle (TCA), and potassium $\mathrm{K}^{+}$channel, ACO, ACC 


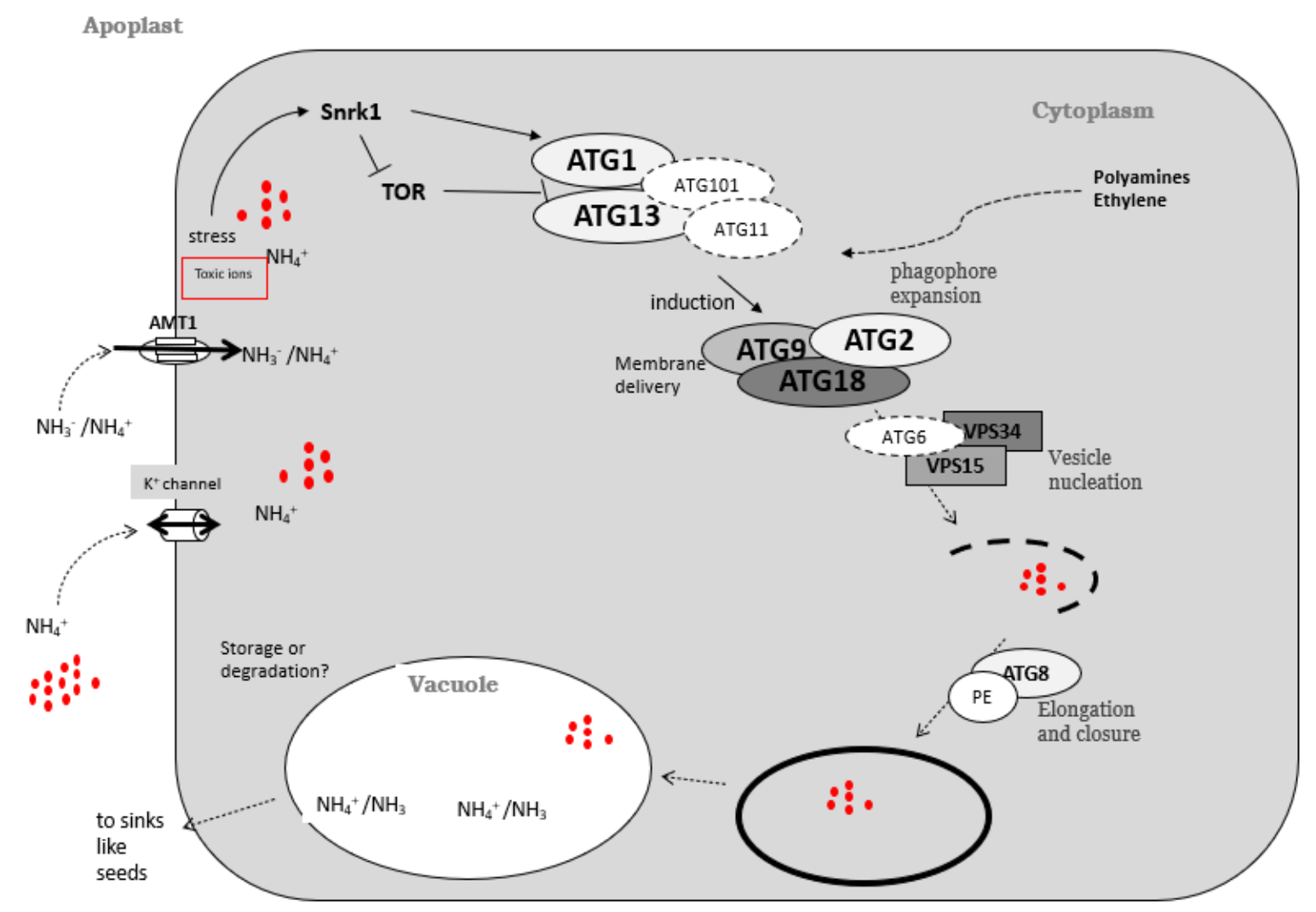

Fig. 8. Putative schematic diagram of the autophagy process in Salicornia neei. Energy sensors SNF-related kinase 1 (SnRK1), target of rapamycin (TOR), autophagy-related protein 1 (ATG1), autophagy-related protein 11 (ATG11), autophagy-related protein 101 (ATG101), autophagy-related protein 13 (ATG13), autophagyrelated protein 9 (ATG9), autophagy-related protein 2 (ATG2), autophagy-related protein 18, vacuolar protein sorting 34 (VPS34), vacuolar protein sorting 15 (VPS15), autophagy-related protein 6 (ATG6), protein sorting 8 (ATG8), phosphatidylenthanolamine (PE) (2.0-fold). In dotted oval ATG not observed. 